\title{
Yaşlı bireylerin geniş aileden kopuş nedenleri ve alternatif yaşam aranjmanlarına dair algıları: Gaziantep örneği ${ }^{2}$
}

\section{Hasan SEVER}

Mersin Üniversitesi, Sosyal Bilimler Enstitüsü, Sosyoloji Anabilim Dalı Doktora Öğrencisi, Mersin / Türkiye ORCID No: https://orcid.org/0000-0002-8946-0411

\begin{abstract}
ÖZET
Modernleșme, endüstrileșme ve kentleșme ile beraber yașanan demografik değismeler, sağllk alanında ilerlemeler ve azalan doğum oranları ile yaşlıllk olgusu dünya genelinde tüm toplumları ilgilendiren bir olguya dönüssmektedir. Bunu yanı sıra, değişen ve dönüssen aile yapısı ve oluşan yeni yaşam kompozisyonları yaşlılık durumunun toplumlar ve bireyler tarafindan farklı biçimlerde deneyimlenmesine yol açmıştır. Bu deneyimlerden biri tek başına yaşamak konusudur. Niteliksel araştırma yöntemine dayanarak derinlemesine görüssmelerle gerçekleștirilen bu çalışma, yaşlı bireylerin geniş aileden kopuş nedenlerini ve tek başına yaşamaya alternatif olarak yeniden evliliği ve huzurevinde yaşamayı nasıl değerlendirdiklerini incelenmiştir. $\mathrm{Bu}$ kapsamda, çalışma Gaziantep ilinde, 65 yaş ve üstü, tek başına, kentte yaşayan, ciddi bir sağlık engeli bulunmayan ve farkl sosyoekonomik düzeylere sahip 30 kişi ile yürütülmüstür. Bu çaIışma, yaşlı bireyler için tek başına yaşama aranjmanının geniş ailenin çözülüşünün bir göstergesi olduğunu ve en ideal yașam aranjmanının çocuklarına yakın tek başına yaşamak olduğunu ortaya koymuştur.
\end{abstract}

\section{MAKALE GEÇMIȘi}

Geliş 29 Temmuz 2019

Kabul 28 Ocak 2020

ANAHTAR KELIMELER

Yaşlılık, yaşam aranjmanı, tek başına yaşama

\section{Reasons for the separation of elderly individuals from the extended family and their perception of alternative life arrangements: The case of Gaziantep}

\begin{abstract}
Demographic changes that occur due to modernization, industrialization and urbanization, as well as the reducing birth rates and the advances in healthcare, aging issue has become an important phenomenon for all societies. In addition, the changing and transforming family structure and growth of new life compositions have led to the societies and individuals experience aging in different ways. One of these experiences is 'to live alone'. This study, which is conducted through in-depth interviews based on qualitative research methodology, examines reasons for the separation of elderly individuals from the extended family and how they evaluate remarriage and living in nursing home as an alternative to live alone. In this context, the study was executed in Gaziantep province with 30 people aged 65 and over, living alone, living in the city, not having a serious health disability and having different socioeconomic levels. This study reveals that the arrangement of living alone for elderly individuals is an indicator of the dissolution of the traditional extended family and that the ideal living arrangement is living alone close to their children.
\end{abstract}

\section{ARTICLE HISTORY}

Received 29 July 2019

Accepted 28 January 2020

\section{KEYWORDS}

Old age, life arrangements, living alone

\section{GİRİS}

Gerek dünyada gerekse Türkiye'de, demografik değişimler, sağlık alanında yaşanan gelişimler ve doğum oranlarında azalma ile beraber gittikçe artan yaşlı nüfusu ve bu artışla ortaya çıkan nüfusun yaşlanma olgusu ve problematiği yaşlılık konusunun daha ciddi çalışılması gerekliliğini ortaya koymuştur. Yaşlılık olgusu çok geniş bir konudur, çünkü yaşlılık kendi içinde heterojen deneyimlere işaret etmektedir. Ailesi ile birlikte, huzurevinde veya tek başına yaşayan, kırda, kentte veya başka biçimlerde yaşayan, fiziksel, bilişsel sağllğa sahip olan veya olmayan yaşlı bireylerin kendi içinde homojen olmadığı; farklı durumlara, dolayısıyla da farklı sorunsallara işaret ettiği ortaya çıkmaktadır. Özellikle modernleşme ve endüstrileşmenin yarattığı toplumsal değișim yaşlıların statülerini, saygınlıklarını ve rollerini negatif yönde değiștirmenin yanı sıra ekonomik durumlarını, sosyal çevrelerini, aile düzenlerini, sağlık durumlarını, yaşlanma süreçlerini ve yaşlılıklarını doğrudan etkilemiştir (Giddens, 2013; Hooyman,

\footnotetext{
${ }^{1}$ Bu çalıșmanın bir bölümü 2019 yılında Denizli'de gerçekleștirilen 10. Ulusal Yaşlılık Kongresi'nde sunulmuştur.

${ }^{2}$ Makalenin Kaynak Olarak Gösterimi: Sever, H. (2020). Yaşlı bireylerin geniş aileden kopuş nedenleri ve alternatif yaşam aranjmanlarına dair algıları: Gaziantep örneği. Yaşlı Sorunları Araştırma Dergisi (YSAD), 13(1), 1-9.

${ }^{3}$ Sorumlu Yazar e-mail: hasan sever@yahoo.com
} 
Kiyak \& Kawamoto, 2015; Quadagno, 2002; Tufan, 2002). Bu değișim "yaşlıların yașam zorluklarını ailenin problemi olmaktan çıkararak kamusal bir problem haline getirmiştir" (Tufan, 2003:22). Yaşlı bireyler bu toplumsal değişim dönüşüm sürecinde yeni yaşam aranjmanları ile karşı karşıya kalmışlardır.

Yaşam aranjmanı, yaşlıların farklı "hane halkı kompozisyonlarından" ve "yașlılıkla baș etme stratejilerinden biri" olup "kendilerine ait olmayan ve dışına itildikleri dünyada nasıl konum aldıkları ve ne tür çözümler ürettikleri" ile ilgilidir (Kalaycıŏ̆lu, Küçükural \& Kurtuluș, 2003:15). Yaşam aranjmanı, yaşlıların "yaş, cinsiyet, gelir ve eğitim düzeylerini, kentsellik-kırsallık" değişkenlerini, "mekâna ilișkin yaşam tercihleri"nin (Şentürk \& Altan, 2015:28) yanı sıra gündelik hayattaki etkinliklerini, sosyalleşme süreçlerini ve aile ilişkilerini içeren derin ve çok yönlü bir kavramdır. Geleneksel geniș ailede birden fazla kușak ile beraber yașayan yașl1lar, yaşanan değişimlerle beraber, yalnız (tek başına) yaşama, eşiyle yaşama, çocuklarının yakınında veya uzağında yaşama, huzurevinde yaşama gibi alternatif yaşam aranjmanları geliştirmek durumunda kalmışlardır (Kalaycıoğlu vd., 2003:18-19).

$\mathrm{Bu}$ çalıșmanın odak konusu olan tek bașına yașama aranjmanı, başta gelişmiş ülkeler olmak üzere dünya genelinde hızla yaygınlaşmaktadır. Tufan'ın da belirttiği gibi, "yalnız yașamak genel bir yaşam stili" haline gelmekte ve gerek dünya genelinde gerekse Türkiye özelinde, değișen ve dönüşen aile yapısında yaşlıların tek başına kalma isteği ve mecburiyeti artmaktadır (Tufan, 2003:54). Türkiye'nin bölgeleri arasındaki ekonomik, kültürel, sosyal nedenlerle aile yapısının içerdiği farklılıklar, kentleşme ve göç olgusuna rağmen büyük ölçüde korunsa da bu farklılıkların zamanla ortadan kalkacağı ve nüfusun da yașlanması ile beraber, Türkiye'de tek başına yaşayan yaşlıların sayısının artacağı tahmin edilmektedir (Murakami, 2014:148; Tufan, 2003:195).

Türkiye genelinde olduğu gibi Gaziantep'te de yașlı nüfusu artmaktadır. TÜİK, adrese dayalı nüfus kayıt sistemi, 2018 verilerine göre Gaziantep ilinin toplam nüfusu 2.028.563'tür. Bu nüfus içerisinde 65 yaş üstü nüfusun 108429 olduğu görülmektedir. 65 yaș üzeri nüfusun toplam nüfusa oranı $\% 5,3$ olarak tespit edilmiştir (TÜİK, 2018). Gaziantep'te cinsiyete göre tek kişilik yaşlı hane halkı oranı ise erkeklerde \%19,5 iken kadınlarda \%80,5 olduğu görülmektedir (TÜİK, 2016).

Gaziantep nüfusu son 30 yılda gerek Şanlıurfa, Kahramanmaraș, Kilis ve Adıyaman gibi çevre illerin kırsal bölgelerinden gerekse Suriye'den aldığı göçle gittikçe artmaktadır. "Kentin ekonomik gelişme hızı göç merkezi olmasının en büyük nedenlerinden biridir" ve "Gaziantep bugün halen Güneydoğu Anadolu bölgesinin sanayi merkezi olma özelliğini korumaktadır" (Geniș \& Adaş, 2011:297). Bununla beraber geleneksel, yerel kültürel yapısını da belli ölçüde koruyan Gaziantep'te "akraba ve/veya hemșeriler gibi geleneksel yardımlaşma ve dayanışma kurumları birinci sırada yer almaktadır" (Geniș \& Adaș, 2011:310). Bu bağlamda bir yandan modern diğer yandan geleneksel kültürü ve ilişkileri barındıran kentte yaşlıların toplumsal konumunun ve koşullarının da değişime uğradı̆̆ı ve yeni yaşam aranjmanlarının ortaya çıktığı görülmektedir.
Bu makale, Gaziantep'te 65 yaş üştü, tek başına yaşayan yaşlı bireylere odaklanan niteliksel bir çalışmaya dayanmaktadır. Çalışmada yaşlı bireylerin değişen toplumsal yapıya adaptasyon süreçlerinde tek bașına yaşama aranjmanını seçmelerindeki temel faktörlerin neler olduğu; başka alternatiflerinin olup olmadığı; bu alternatifler - çocuklarıyla geniş ailede yaşamak, huzurevinde yaşamak, yeniden evlenmek- hakkında ne düșündükleri incelenmiștir.

\section{TEORİK ÇERÇEVE: YAŞLILIK TEORİLERİ}

Yaşlılık teorileri yaşlanma olgusunu ve yaşlılık sürecini anlayabilmek, betimleyebilmek ve ilgili sorunlara çözüm bulabilmek için çeșitli bakış açıları sunmuşlardır. Ancak belirtmek gerekir ki hiçbir teorinin yaşlılık durumunu ya da aynı yaş grubu içindeki insanların, neden farklı olduğunu tek başına açıklayabilme gücü yoktur. Bu çalıșma, yaşlılık teorileri içinde Modernleșme, Rol, Politik Ekonomi ve Feminist yaşlılık kuramlarına dayanarak modernleşme ve kentleşme sürecinde yaşlı bireylerin yaşam aranjmanı seçimini belirleyen dinamikleri incelemektedir. Bu bağlamda, çalışma yaşlı bireylerin geleneksel ailenin çözülme sürecinde nasıl tekilleştiğini, bununla beraber alternatif olarak yeniden evlilik ve huzurevi yaşam aranjmanlarına dair algılarını ve geleneksellikten modernliğe geçiș sürecinde nasıl bir yaşam aranjmanına ihtiyaç duyduklarını anlamaya çalışır.

Modernleşme kuramın göre "teknolojik değişmeler, yaşlıların yaşam deneyimine ya da bilgeliğine az değer verilmesine neden olmuş, bunun sonucunda yaşlılarda statü ve güç kaybı meydana gelmiștir" (Görgün-Baran, 2004:50). Quadagno (2002) gelişme süreçlerini yaşlıların statüsüne bağlayan ilk kişinin Ernest Burgess olduğunu belirtir. Burgess "Batı Toplumlarında Yaşlanma" (1960) adlı eserinde endüstri devriminin yaşlılar için negatif etkileri olduğunu açılklarken, emeğin evden fabrikaya taşındığında kendi işinde çalışanların sayıca azaldığını, yaşlıların ekonomik bağımsızlıklarını kaybettiğini ve emekli olmaya zorlandıklarını anlatmıştır. Kentleşme genç insanları kırsal bölgelerden kente çekmiș, geniș haneleri dağıtmıș ve yașlıları izole etmiş ve yaşlılar "rolsüzlük rolüne" hapsedilmiştir (Quadagno, 2002: 42).

Rol Kuramına göre ise, rol kaybının yaşlılık deneyimini etkileyen önemli faktörlerden biri olduğunu vurgular. Her insan yaşamı boyunca öğrenci, anne, eş, kız çocuğu, işçi, gönüllü ve büyükanne gibi çeşitli roller oynar (Cottrell, 1942, Akt. Hooyman vd., 2015: 141). Bu roller zaman içinde değiş̧ir ve kişi farklı yaşlarda farklı rol durumlarıyla hayatını sürdürmek zorunda kalır (Kaygusuz, 2008: 236). Yani, insanları bir sosyal varlık olarak tanımlayan bu roller sırasıyla organize edildiğinden, her bir rol belirli bir yaș ve hayat așaması ile ilișkilendirilmiştir. $\mathrm{Bu}$ rollerden herhangi birinin işsizlik, emeklilik, dulluk veya diğer nedenlerle kaybı, insanların aktif yaşlanmanın keyfini çıkarmasına yarayan iyi olma halini ve firsatlarını etkiler (Hooyman vd., 2015:141).

Öte yandan Politik Ekonomi kurama göre, yașlanma deneyimine ve yaşa dayalı eşitsizliğe bireysel faktörler değil, politik ve ekonomik statülerinin yanı sıra iktidar ve toplumsal kaynakların (refah devleti eliyle) kontrolü ve dağıtım biçimi neden olur. Kuram, sosyal sınıfı 
yaşlı insanların konumunu ve yaşam doyumunu belirleyen en temel faktör olarak görür (Quadagno, 2002:53; Hooyman vd., 2015:151). Feminist teori ise, yaşlı erkek ve yaşlı kadınlar arasındaki ekonomik ve iktidar ilişkilerine, mikro seviyede ise sosyal anlamlar bağlamında toplumsal cinsiyete odaklanarak bireyler ve sosyal yapılar arasında bağ kurarlar. Feminist Teori, kavramsal olarak makro seviyede cinsiyet tabakalaşması, iktidar yapıları ve toplumsal kurumlara; mikro seviyede ise bakım sağlama ve aile işleri, sosyal anlamlar ve kimliği temel alır (Bengtson, Burgess \& Parrott, 1997:80).

$\mathrm{Bu}$ teoriler modern kentsel alanlarda yaşayan yaşlıların durumunu ortaya koymak için model oluşturabilirler. Ancak temelde Batı toplumlarına odaklanarak ortaya konan bu teorilerin evrensel olma ideaları yoktur. Yaşlı kişileri etkileyen sosyal, ekonomik ve politik koşullar değişime uğradığından, pek çok disiplin içinde yeni teorik perspektiflerin geliștirilmesi ya da öncekilerin farklı kültürlere, bağlamlara ve durumlara dair bilgiler toplanarak gözden geçirilmesi gerekir (Hooyman vd., 2015:157).

Söz konusu yaşlılık teorileri ışığında, bu çalıșma, günümüz değișen aile yapısı içinde yaşlı bireylerin rol ve statülerindeki değişimin yaşlılık deneyimlerini ve yaşam aranjmanlarına dair algı ve tutumlarını nasıl etkilediğini inceler.

\section{MATERYAL VE YÖNTEM}

Temel olarak niteliksel yöntemle gerçekleştirilen bu çalışma kapsamında, kent ortamında, tek başına yaşayan, ciddi bir sağlık engeli bulunmayan 65 yaş ve üstü bireyler seçilmiş ve 30 kişi ile derinlemesine görüşme ve dörder kişilik iki odak görüşme yürütülmüştür.

Hem yașlılık deneyiminin çeșitliliğini ve karmaşık yapısını ortaya koyabilmek, hem de araştırmanın geçerliliğini sağlamak ve ampirik genellemeler yapabilmek için görüșmeler Gaziantep'in ilinin iki merkez ilçesi olan Şehitkamil ve Şahinbey ilçelerinde yürütülmüştür. Şehitkâmil ilçesinde, İncesu, Gazi, Karşıyaka, Sarıgüllük, Fatih, Emek, Yaprak, İbrahimli, Seyrantepe, Hürriyet ve Hacıbaba mahallelerinde ve Șahinbey ilçesinde bulunan Akyol, Güneykent, Bozalar, Yukarıbayır, Karataş, Hoşgör, Kurtuluş, Gündoğdu, Düztepe, Şehreküstü mahallelerinde farklı sosyo-ekonomik ve kültürel düzeylere sahip yaşlı bireylerle mülakatlar gerçekleştirilmiș ve bu görüșmeler katılımcı gözlem ile pekiștirilmiştir. Gerek bireysel gerekse odak görüşmelerde katılımcılara yarı yapılandırılmış 50 soruluk bir anket formu uygulanmıș ve derinlemesine görüșmeler gerçekleștirilmiştir. Görüşülen kişilerin içsel yaşam deneyimlerine ve duygularına birinci ağızdan ulașılmaya çalışılmış ve katılımcılar, özel hayatın gizliliği dikkate alınarak, çalışmada takma adlarıyla yer almışlardır. Araştırma sahasında veriler, katılımcıların izin verdiği ölçüde, ses kaydı alınarak ya da not tutularak toplanmış ve kayıtlar çözümlenmiștir.

Çalışmanın evreni Gaziantep ilinin iki merkez ilçesi olan Sehitkâmil ve Șahinbey ilçelerinde tek bașına ya-

\footnotetext{
${ }^{4}$ Gaziantep ilinde de 65 yaş üstü yaşlı nüfus içinde yaşlı kadınların sayısının $52.769(\% 5,8)$ yaşlı erkeklerin sayısının 43.544 $(\% 4,4)$ olduğu görülmektedir (TÜİK, 2016).
}

şayan yaşlı bireyleri kapsamaktadır. Çalışmanın örneklemini ise bu evren içerisinde 65 yaș ve üstü (65-89) olup, evde tek başına yaşayan sağlıklı 30 yaşlı birey olușturmaktadır. Katılımcılar öncelikle amaçsal örnekleme yöntemi ile seçilmiş ve kartopu tekniği kullanılarak diğer katılımcılara ulaşılmıştır.

Türkiye'de kadınların yaşlı nüfus oranları erkeklerinkinden daha fazla ${ }^{4}$ olduğu için örneklem grubunu oluşturan ve tek başına yaşayan 30 yaşlı bireyin 18'i kadınlardan, 12'si erkeklerden oluşmaktadır. Katılımcılar 24'ünün eși vefat etmiş, 5'i boșanmıș, 1'i de hiç evlenmemiştir. Eğitim durumu açısından katılımcıların yarısı okur-yazar değilken 3'ü okuryazar, 6'sı ilkokul mezunu 2'si lise mezunu, 4'ü ise üniversite mezunudur. 30 katılımcıdan, 23'ünün sosyal güvencesi (Emeklik Sandığı ve Bağ-kur) bulunmakta; 6'sı Yașlılık Aylığı (Yeșil Kart) ve 1'i Dul Aylığı almaktadır. Barınma açısından katılımcıların 20'si apartman dairesinde, 5'i müstakil evde, 5'i de gecekonduda yaşamaktadır. Ayrıca, katılımcların 22'si kendi evinde 5'i kirada, 3'ü ise çocuğunun ya da akrabasının evinde oturmaktadır.

$\mathrm{Bu}$ nitel araștırmada verilerinin analizi yorumsamacı bir perspektif ile gerçekleștirilmiştir. Sosyolojik bakış açısı, birey ile toplum arasındaki bağlantıları anlamaya yöneliktir. Bu çalışma da yaşlılık deneyimlerinin toplumsal değişimden nasıl etkilendiği ve bu etkilenme sürecinde değișen aile kompozisyonlarının aldığı biçim içerisinde yaşlı bireyin tekilleşmesini, aile ve toplum içerisindeki yerini anlamaya çalışmaktadır. Bu çalıșmanın evrenini evde tek başına yaşayan yaşlılarla sınırlamak oldukça zor bir karar verme süreci gerektirmiştir. Çünkü ileri yaş grupları o kadar çeşitlidir ki sağlığı yerinde olan, olmayan, ailesiyle yaşayan, tek başına yaşayan, huzurevinde yaşayan, farklı hastalıklara sahip olan yaşlı grupları gibi pek çok grubu kapsar.

$\mathrm{Bu}$ çalışma, evde tek başına yaşayan yaşlı bireyleri merkeze almıştır. Çünkü toplumsal değişim sürecinde ve dolayısıyla değișen aile kompozisyonunda yaşlı bireyler gittikçe tekilleşmektedir. Bu nedenle, çalışma tek başına yaşayan/yaşamaya çalışan yaşlı bireylerin yaşam koşulları, yaşlılık deneyimleri, duygu ve düșünceleri arasındaki ilişkileri kavrayarak yaşam aranjmanlarına dair pratikleri ve algılarının nasıl biçimlendiğini anlamaya çalışmaktadır. Bu kapsamda katılımcılara "tek başına yașama" aranjmanını hangi değişkenlerden dolayı seçtikleri, bunun bir tercih mi ya da zorunluluk mu olduğu, geniş aileden kopuş süreçleri ve bu yaşam aranjmanına alternatif olarak huzurevinde yaşamayı, yeniden evlenmeyi nasıl değerlendirdikleri ve kendileri için en ideal yaşam aranjmanının ne olduğu sorulmuştur.

\section{BULGULAR VE TARTIŞMA}

\subsection{Geniş aileden koparak tek başına yaşamak}

Modernleşme ve endüstrileşmenin yarattığı toplumsal değişim, geleneksel geniş ailede birden fazla kuşak ile yaşayan yaşlıların da yaşamını değiștirmiş ve yaşanan değişimle beraber yaşlı bireyler kendilerine alternatif yașam aranjmanları geliștirmek durumunda kalmıșlardır. Yaşlı bireylerin bu aranjmanlardan biri olan evde 
tek başına yaşamayı seçmelerindeki temel sebepler bu konuya dair Türkiye'de yapılan diğer yașlılık çalıșmalarda da tespit edildiği üzere - "dulluk durumu" (Tufan, Zengin \& Köse, 2017:41), "kendi kendine yetmek," "yaşanan çevreyi değiştirmemek," "mevcut durumlarından memnuniyet duymak," (Aközer, Nuhrat \& Say, 2011:118) ve kuşakların "norm ve değerleri ve algı düzeylerindeki farklılıktır" (Görgün-Baran, Kalınkara, Aral, Baran, Akın \& Özkan, 2005:23). Zaten geniş ailede yaşama aranjmanı, kimi yaşlı bireyler için artık mümkün değilken, kimileri için de yarattığı dezavantajlardan dolayı tercih edilmemektedir. Bu bağlamda yaşlı bireylerin sağlık, sosyal ve ekonomik bakımdan uygun koşullara sahip olmaları durumunda tek başına yaşamayı seçtikleri görülmektedir (bkz. Quadagno, 2002; Baran, 2004; Hablemitoğlu \& Özmete, 2010). Geniş ailenin çözülüşüyle beraber yaşlı bireylerin değișen durumunu kendi öznel değerlendirmeleri üzerinden anlayabilmek için bu konuda, katılımcıların tek başına yaşamayı neden seçtikleri; bu seçimin tercih mi yoksa zorunluluk mu olduğu, başka alternatiflerinin olup olmadığı ve geniş aile içinde yaşamaya nasıl anlam verdikleri incelenmiștir.

Katılımcılarla yapılan görüşmelerde, geniş aile içinde yaşamanın bazı katılımcılar için mümkün olmadı̆̆ı, bazı katılımcılar tarafından da yarattığı dezavantajlardan dolayı tercih edilmediği tespit edilmiştir. Geniş ailede (çocuklarıyla) yașamak istememelerinin nedenlerini katılımcıların 11 'i "kendimi çocuklarımda rahat hissetmiyorum," 9'u "'çocuklarımdan gel bizimle kal' diyen olmadı," 6'sı "çocuklarımı rahatsız etmek istemiyorum," 2'si "çocuklarımın ekonomik durumları kötü" ve diğer 2'si ise "ev dar" olarak belirtmişlerdir.

Çalıșmada, yașlı bireyler bu yeni yașam ritmine kendilerini uyarlamaya çalışırken, bu süreci kendi evlerinde geçirmelerinin kendilerine iyi geldiğini ve en temelde bu nedenle tek başına yaşamayı seçtiklerini belirtmişlerdir. Ancak bu süreci başkalarının ritmine göre; gelin ya da damatla birlikte yaşamanın kendilerini bu sürece uyarlayabilmelerine engel teşkil ettiği çoğu katılımcı tarafından ifade edilmiştir.

Uşağin klymetini bilirse en doğrusu uşaklarla kalmaktır. Bu eskiden oluyordu ama șimdi öyle değil. Gece acıkırsam çocukların evinde rahat olamam ama kendi evimde istediğim zaman mutfağa gidiyorum. Gel bizimle yașa diyen de olmuyor da gidersem bana kal derler ama sonra hemen eve gelmek istiyorum. Onlarda rahat hissetmiyorum. Simdi öyle güzel hürmet edilirse neden kalmayayım, ama iște el kızı olmuyor, el oğlu da olmuyor, yani yalnız kalmak daha iyi (Melek, kadın, 74, orta gelir, okuryazar değil).

Daha önce çocuğumla kallyordum, sonra başka bir eve çıktım. Yalnız kalmak istedim. Gelinim ve oğlumdan şikâyetçi değilim ama dayanacak gücüm kalmadı. Mesela, sabahtan kalkarsin ekmek beklersin, kahvaltı beklersin, onlar uyanacak öyle hep beraber kahvaltı yapılacak, ama ben erken uyanıyorum hareket edemiyorum (...) En doğrusu yalnız yaşamak. Geçti o dönem artı uşaklarla kalınmaz (Esma, kadın, 71, orta gelir, okuryazar değil).

Söz konusu kuşaklar arası ritim farklılıkları, yaşlı kişilerin hayatını değişik biçimlerde zorlaştırmaktadır. Bu- nun önemli nedenleri ev içinde diledikleri zaman hareket etme ve beslenme özgürlüklerinin olmamasıdır. Genel olarak katılımcılar geniş ailede çocuklarıyla beraber yaşadıklarında, gece gürültü yapmamak için TV izleyemediklerini, tuvalet ihtiyacını gidermede zorluk çektiklerini, mutfağı istedikleri zamanda kullanamadıklarını, acıktıkları halde yemek saatlerini beklemek zorunda kaldıklarını belirtmişlerdir. Bunlara uyku ve uyanma saatleri konusundaki farklar da eklenince, yaşlı bireylerin yaşam ritimlerinin çocukları ve torunlarınınkinden farklı olması, onlarla beraber yașama konusunda pek çok sorunla karşılaşmalarına neden olmaktadır. Tek başına yaşayan katılımcıların çoğu ailenin değișen biçimine vurgu yaparak, çocuklarını ve torunlarını rahatsız etmemek ve rahatsız olmamak için çocukları isteseler de istemeseler de artık geniş aile ortamında kalamayacaklarını ifade etmişlerdir.

Cocuklarımdan gel bizimle kal diyen oldu (...) Ben gençlerle kalamam, aynı evde nasıl olur, yani benden rahatsiz olurlar, ben de onlardan rahatsiz olurum (...) Ben bazen çocuklarımın evine gidiyorum 23 saatten fazla kalamıyorum, gençler yaşhlıarla ilgilenmiyor, kendi evime geliyorum. Bunun için tek başına yaşamak en iyisi (Ibrahim, erkek, 80, üst gelir, ilkokul mezunu).

Burada kuşaklar arası uyumsuzluğu yaratan faktörler sadece gece uykusuzluğu değil, aynı zamanda beslenme biçimi ve öğün saatleri konusunda yaşanan farklılıklardır. Yașlı kișilerin uyku ve beslenme düzenlerinde, çeşitli biyolojik ve psikolojik faktörlerin ve yaşama biçimindeki değişimlerin etkisiyle sorunlar yaşanabileceği, uyku ve beslenme bozukluklarına sahip olabilecekleri, hatta bunların depresyonla ilişkili olabileceği ve bu nedenle yașlılarda dikkate alınması gereken bir konu olduğu geriatri ve tıp alanlarında yürütülen çalışmalarla ortaya konmuştur (Kalenderoğlu, Yumru, Selek, Cansel, Virit, \& Savaş, 2007; Aslan, Şengelen \& Bilir, 2008; Bingöl, Varma, Enli \& Karaca, 2017; Aksoydan, 2008). Dolayısıyla yașlı bireylerin yașam ritimlerindeki farklılıkların çocukları ve torunlarıyla bir arada yaşayabilmelerini engelleyen önemli bir sebep olduğu görülmektedir.

Yașlı bireyin kendi kendine yetebilme ve bağımsız hareket edebilme isteği, modernleşme teorisinde vurgulanan yaşlıların "statü kaybı"na bir direnç olarak algılanabilir. Nitekim yașlı bireylerin sahip olduğu bağımsızlığı sürdürme isteği "özgürlük" ve "mutluluk" ile ilişkilendirilmiştir.

Gider gezersin ișini yaparsın, hesabını gelirini giderini yaparsın, özgür ve mutlu yașarsın. Bu büyüklerin sözüdür. (...) Yaşlının mutlu olacağı yer kendi evidir, yalnız kalmasıdır ama çocukları yakın olsun arar ara gidip gelsin, en güzel yașam yașlılıkta böyle olur (...) KIzımla da beraber kalmak istemem, o el oğlu yani daha kötü. Bu yașta daha hassas oluyor insan (Esma, kadın, 71, orta gelir, okuryazar değil).

Meral hanım kendi evinde tek başına yaşama tercihine eșlik eden "özgürlük" ve "mutluluk" duygularına bir de "aidiyet" duygusunu eklemiștir.

Ben çocuklarımla da kaldım ama artk istemiyorum. Kendi evimde rahatım. Yani çocuklarında tuvaletin bile sayıllyormuş gibi geliyor, sanki misafirlikteymiș gibi oluyor, yani belki de öyle bir șey yok ama öyle düșünüyorsun yani rahat değilsin (...) Bir keresinde 
benim klyafetleri bir dolaptan başka bir dolaba taşımıșlardı. Buna ben çok üzüldüm. Benim haberim olmadan böyle bir şey yapıldı, bundan alındım, kendimi oraya ait hissetmedim (Meral, kadın, 70, üstgelir, ilkokul mezunu).

Öte yandan, yaşlı bireyin tek başına yaşama kararı alabilmesi için öncelikle sağlı̆ının kendi kendine yetebilecek kadar iyi olması ve kendi gündelik işlerini belli bir ölçüde yapabiliyor olması, belli bir ekonomik gelire sahip olması ve tek başına yaşama yatkınlığına sahip olmasının gerekli olduğu görülmektedir. Yaşlılığın Politik Ekonomisi teorisi yaşlılığı makro bir toplumsal çerçeveden analiz eder ve temelde yașlanma deneyimini yaşa dayalı eșitsizliğe, toplumsal kaynakların kontrol ve dağıtım biçimlerine bağlar (Quadagno, 2002).

Bu yaklașıma paralel olarak, bu çalıșmada da sözü edilen fiziksel, maddi ve manevi kaynaklara sahip yaşlı bireylerin tek başına yaşamayı bağımsız ve özgür yaşamak olarak avantajlı bir durum olarak değerlendirdiği görülmüștür. Ancak, düşük sosyo-ekonomik düzeye sahip olan yașlı bireylerin yapısal koșullarının iyi olmaması durumunda - örneğin, düșük gelir, yetersiz eğitim, kötü yaşam koşulları ve hastalık durumları - tek bașına yaşamayı olabildiğince zor koșullar altında geçirdikleri, bu seçimi yapmak zorunda kaldıkları, tek başına yașamanın onlar için dezavantajlı bir durum olduğu ve bu durumun yaşam memnuniyetlerini olumsuz etkilediği tespit edilmiştir.

Gönüllü veya zorunlu olarak kendini geniş ailede konumlandıramayan ve tek bașına yașayan yașlı bireylerin seçebileceği diğer iki alternatifin yaşama aranjmanı huzurevinde yaşamak ve evlenerek eşle beraber yaşamak olduğu söylenebilir. Bu iki alternatif yaşama aranjmanına dair algıları da katılımcıların tek başına yaşama kararlarını etkilemektedir.

\subsection{Tek başına yaşayan yaşhlıarın huzurevi algıSı}

Yaşlı kuşakların modernleşmeye bağlı olarak değișime maruz kalan maddi ve sosyal çevreleri yașlanma süreçlerini ve yașlılıklarını doğrudan etkilemektedir. Bu değișim "yaşlıların yaşam zorluklarını ailenin problemi olmaktan çlkararak kamusal bir problem haline getirmiş" (Tufan, 2003:22), "yaşlıların bakımı da anonimleşip, huzurevlerinde yerine getirilen bir kamu hizmetine dönüșmüștür" (Aytaç, 2012:100). Ancak Türkiye'de yaşlılık ile ilgili olarak yapılan çalışmalar, yaşlıların huzurevine genelde olumsuz bir tutum sergilediklerini ortaya koymaktadır (İçli, 2004; Karaca, 2010; Kalaycıoğlu vd., 2003). Bu nedenle, bu çalıșma modernleșmenin ve kentleșmenin yarattığı koșullar ile geleneksellik arasında kalan yaşlı bireylerin yaşam aranjmanlarını seçerken neye önem verdiklerini ve bu anlamda geniș ailede yaşamaya bir alternatif olarak huzurevinde yaşamaya dair algılarını da anlamaya çalışmaktadır.

Gaziantep'te tek bașına yașayan yașlı bireylerle yürütülen bu çalışmada da görüşülen 30 kişinin 29'u yani \% 96,7'si huzurevinde kalmaya yönelik pek de olumlu bir yaklaşım sergilemediği, hatta tek başına yaşamanın dezavantajlarına fazlasıyla sahip olan yaşlı bireylerin bile bir alternatif olarak huzurevine yönelik algıları genelde olumsuz olduğu tespit edilmiştir. Yaşlı bireylerin huzurevlerine dair olumsuz toplumsal algidan beslenen bu düșüncelerinin huzurevinde yașamanın bir statü kaybı olduğu fikriyle de pekiștirildiği görülmektedir.

Bu kișilerin huzurevine dair bu olumsuz algıya sahip olmalarının temelde iki nedeni bulunmaktadır. Birincisi, huzurevinin toplumsal açıdan negatif bir konuma sahip olmasıdır. Özellikle geleneksel ilișkilerinin ağır bastığı Gaziantep'te yaşlıları huzurevine bırakmak bir "ayıbın" göstergesi olarak yorumlanmaktadır. Diğer bir deyişle, yaşlı bireyin huzurevi yerine evde tek başına yaşaması sosyal çevre tarafından daha makbul niteliktedir. Huzurevi'nin Gaziantepli yaşlılar tarafından "düşkünler evi" olarak ifade edilmesi bu olumsuz toplumsal algının inşasının bir yansımasıdır. Bu konuya dair Güler Hanım, Hacer Hanım ve Mustafa Bey fikirlerini şöyle ifade etmişlerdir.

Ne! huzurevi mi, benim için huzurevi yok çocuğum yok, koskoca güler hanımın sonu huzurevi derler ve sonra Güler Hanım'ın uşakları annelerini huzurevine koydu derler, ölürüm daha iyi oğlum istemem istemem (Güler, kadın, 73, altgelir, okuryazardeğil).

Huzurevine gidip rezil olmak var, hem çocuklar hem de yaşl kişi rezil oluyor. Cevreden bak, annesini babasını huzurevine verdi denir ya da yașlıya bak çocukları tarafindan terk edildi denir. Íki ssekilde de huzurevi çok kötü, yani hem yașlı hem de çocuklar huzursuz olur (Hacer, kadın, 73, orta gelir, üniversite mezunu)

Bunu bir ayıp olarak görüyorum kendime yakıştrrmiyorum, huzurevi olmaz. Yalnız ev ișleri falan yapamazsa tek çare oğlunun yanında kalması (...) Huzurevinde kalmak hiç iyi bir șey değil, millet ne der? Huzurevi olmaz (Mustafa, erkek, 80, orta gelir, okuryazar değil).

Görüşülen kişilerin huzurevine dair olumsuz alglarının ikinci nedeni ise, huzurevinin yașanılacak bir yer olmadığına dair fikirleridir. Huzurevinin kişinin özgürlüğünü kaybedeceği, kötü muameleye maruz kalabileceği, hatta fiziksel ve psikolojik șiddet görebileceği bir ortam olarak düşünülmesidir. Bazı yașlılara yönelik istismar haberlerinin ve huzurevlerinin "medyada yansitılma biçimi”nin (Aközer vd., 2011:123) bu olumsuz huzurevi algisını pekiștirdiği görülmektedir. Huzurevini, Tarkk Bey bir "cezaevi"ne; Cennet Hanım "şiddet uygulayan bir yer"e; Veli Bey ise "tahammül edilmesi zor" bir yere benzetmiștir. Toplumda huzurevine dair olumsuz algının kulaktan dolma bilgilerle, söylencelere dönüștürüldüğü ve bu olumsuz algıların gerek yaşlı bireyler gerekse çevre tarafindan anlatılarak yeniden üretildiği görülmektedir. Katılımclar huzurevini genelde bir yaşam aranjmanı olarak seçme taraftarı olmadıklarını ancak "kimsesiz" yaşlı bireylerin huzurevini tercih edebileceğini ifade etmektedirler. Bu açıdan yaşlının kimsesizliği çocuklarıyla olan iletişim durumuna bağlanmaktadır. Yaşlılar açısından huzurevi çocuklarıyla iletişimi kopan, sağlık durumu tamamen bozulan, kendilerine bakamayan diğer bir ifadeyle "düșmüşler için bir son çare" olarak görmektedirler (Kalaycıŏglu vd., 2003: 167). Hüseyin Bey huzurevinin aile desteği olmadığı takdirde bir seçenek olabileceğini belirtmișlerdir.

Kendime bakamayacak kadar yaşlanır, kötü olursam, neden olmasın? Kişi kendi evinde yaşayabileceği kadar yaşar, ancak kendine bakamayacak noktaya gelirse huzurevine gidebilir (Hüseyin, erkek,72, alt gelir, erkek, okuryazar). 
Aközer ve ark. (2011) çalışmalarında "huzurevine yönelik olumlu eğilim" ile "aileye yönelik olumsuz eğilim" arasında bir ilişki kurarlar. "Aileye yönelik olumsuz eğilim çocuklar ya da gelin/damat tarafından istenmeme kaygısından ve çocuklara yük olmama isteğinden kaynaklanmaktadır. Huzurevine yönelik olumlu eğilim"in temelinde ise kendi yaşıtlarıyla birlikte olmak ve huzurevinin rahatlı̆̆ı vardır" (2011:115). Ancak, bu araştırmada ortaya çıkan sonuç, huzurevini yaşlı birey için kabul edilebilir hale getiren en önemli şeyin, "huzurevine yönelik olumlu algıları" değil genelde "aileye yönelik olumsuz eğilimleri" ya da tek başına yaşayamama durumu olduğudur.

Sözü edilen huzurevi karşıtı toplumsal baskıya rağmen, katılımclar arasında huzurevini tercih etmek zorunda kalan bir kişi bulunmaktadır. Bu yaşlı bireyin evde şiddete maruz kaldığından dolayı yalnız yaşama kararı aldığı, ancak gündelik pratiklerini yerine getiremediği için son seçenek olarak huzurevini istediği görülmektedir.

Şimdi tek başıma yaşıyorum, gücüm kuvvetim yok, sadece ayakta durabiliyorum, bașka bir șey yapamıyorum (...) Adımı yazdılar, önümde 11 kişi var. $\mathrm{Hu}$ zurevinde yer yokmus, ben de bekliyorum, artık beni alsınlar diyorum (Melek, kadın, 85, alt gelir, ilkokul terk).

Huzurevinde yer bulmak yaşlıların sandığı kadar kolay olmamaktadır. Huzurevi kontenjanlarının sınırlı oluşu dolayısıyla, yaşlılar uygun görüldükleri takdirde bile bir süre beklemek zorunda kalabilmektedirler. Sonuç olarak yaşlıların huzurevine dair fikirlerinin olumsuz olduğu ancak bir yaşam aranjmanı olarak "son tercih" ve "çaresizlik" olarak görüldüğü söylenebilir.

\subsection{Tek başına yaşayan yaşı̆ bireylerde yeniden evlilik algisI}

Yapılan çalıșmada elde edilen veri ve bulgular, katılımclların tek başına yașamaya bir alternatif olarak, huzurevi konusunda olduğu gibi, yeniden evlilik konusuna da pek sıcak bakmadığını ortaya koymaktadır. 30 yaşlı bireyden 25'nin yeniden evliliğe karşı çıktığı, 5'inin ise evlenmek istediği görülmektedir. Evlilik olgusuna dair düşünceler cinsiyet açısından kısmen farklılık göstermektedir. Görüșülen 18 kadının tamamı, 12 erkeğin ise 7'si yeniden evliliğe olumsuz bakmaktadır. Bu yaklaşımın ortak nedenleri olsa da kadın ve erkek yaşlı bireylerin nedenselleștirmeleri farklllık göstermektedir.

Kadınların yeniden evlilik üzerine olumsuz fikre sahip olmalarının bir nedeni yașlılık öncesi dönemde eșini kaybetmiş veya boşanmış çocuklu dul kadınların yeniden evlenmesini hoş görmeyen toplumsal bakış açısıdır. Hatta yeniden evlilik, kadınlar için "konuşulması bile kötü", "uygun olmayan" ve "ihtiyaç duyulmayan" bir olgu olarak vurgulanmakta ya da toplumsal olarak böyle uygun görüldüğü için bu şekilde ifade edilmektedir. Kadınlar için yeniden evlenme konusunun bir toplumsal tabu olduğunu Elmas Hanım (Elmas, kadın, 84, orta gelir, okuryazar değil) "evlilik, abbov çok kötü, tövbe tövbe bizde öyle bir şey olmaz, yok oğlum konuşulması bile kötü yok yok yok, bizde gözünü oyarlar valla" diye ifade ederken, Esma Hanım (Esma, kadın, 71 , orta gelir, okuryazar değil) yaşadığı sıkıntılara rağmen evlenmemesini "eșim vefat edince çok zorluk yaşadım, ben kadınların kaşını bıyığını alarak geçindim, ama ikinci bir evlilik düşünmedim, çocuklarım vardı, Antep'e uymaz" diyerek ifade etmiştir.

Bu konunun tabu olmasının yanı sıra kadınların yeniden evlenmeye sıcak bakmamalarının diğer nedenleri ise; özellikle düzenli bir gelirleri varsa ve kendilerine yetebiliyorlarsa buna gerek duymamaları; "kahır çekmek, "kimseye katlanmak istememeleri" ve özgür yaşama arzularıdır.

Ben ikinci evlilik düșünmüyorum, kendi ayaklarım üzerinde duruyorum ve geçiniyorum. (...) Hiç gerek yok. Yalnızlık daha güzel, gitgez dolaş özgürsün, arkadașlarına zaman ayır, istediğin yere gidersin kimseye bağlı değilsin. (...) Oraya sen bir çizgi çiz (Hacer, kadın, 73, orta gelir, üniversite mezunu).

Öte yandan, kadınların yeniden evlenmekten kaçınmalarının diğer bir önemli nedeni, kadın için yeniden evlenmenin, bedel ödenmesi gereken bir şey olmasıdır. Bu bedel çoğunlukla kişinin sosyal çevresinin ve özellikle çocuklarının ilgisini, gerek duygusal gerekse sosyal ve ekonomik desteğini kaybetmek olarak tarif edilmiștir. Selma Hanım bu konuda toplumun kadın ve erkeğe uyguladığı çifte standardı da betimlemiștir.

Yeniden evlenirsem, çocuklarım tepki gösterir, çocuklarımla bağlarım kopar, beni dişlarlar. Yani bu dışlanmayı yaşayacağıma yalnız yaşamak daha mantıklı (...) Ben evlilik düşünmüyorum, ama düşünenlere saygı duyuyorum. (Selma, kadın, 65, orta gelir, lise mezunu).

Aslında, Gaziantep örneğinde kadınların yeniden evlilik üzerine olumsuz fikirleri geleneksel toplumsal yapı ile ilişkilidir. Gerek yaşlılık öncesi dönemde gerekse yașlılık döneminde eșini kaybederek veya eșinden boșanarak "dul" statüsüne geçen kadınların toplumsal hareket alanı daralmaktadır. "Türkiye'de dulluk, bilhassa kadınlar için normatif bir hale gelmektedir (...) dul erkeklerle karşılaştırıldığında, dul kadınların ölünceye değin evlenmedikleri ve dul kalarak yaşamlarını sürdürdükleri bilinmektedir" (Arber, Devidson \& Ginn, 2003, akt. Arun, \& Arun, 2011:1521). "Dulluk" dezavantajlı bir statü olarak yașlı bireyin sosyalleșme biçiminden, ekonomik durumuna ve gündelik pratiklerine kadar yaşamın her alanında yaşamını önemli derece etkilemektedir. Yeniden evliliğe karar verme konusunda kadının toplumsal statüsü etkili olsa da, kișilerin yaşlılık dönemi ve öncesinde sahip oldukları yatkınlıklar evliliğe dair düșüncelerini etkilemektedir. Kadın katılımcların bu konudaki bakış açıları genelde olumsuzdur. Ancak eğitim seviyesi yükseldikçe, kendileri evlenmeyi düşünmeseler bile başkalarının evliliğine dair daha olumlu bir fikre sahip olabilmektedirler.

Erkek katılımcılar, yeniden evlenme olgusuna olumlu ve olumsuz olmak üzere çeșitli açllardan yaklașmaktadırlar. Kadınların vurguladıkları "evlenme durumunda çocukları tarafından dışlanma korkusu" çoğunlukla erkekler tarafindan da ileri sürülmektedir. Ancak erkeklerde bunun sebebi daha çok "mülk sahibi" olarak "mülkünü paylaşma, kaybetme veya dolandırılma" korkusu olarak görülmektedir. Kadınların temel korkusu, toplumsal cinsiyet açısından çocukları ve toplum tarafindan dışlanmak iken, erkeklerin temel korkusu kendilerine kalacak mirasın parçalanmasını istemeyen ve bu nedenle evlilik isteklerine karșı çlkabilecek çocukları tarafından dışlanma korkusudur. Erkek yaşlıların temelde ekonomik eksenli bir endiședen dolayı, ancak 
bunun yanı sıra "yaş itibariyle çekilme" ve dolayısıyla geleceğe dair bir plan yapmama durumu veya "eşinin yerine başkasını koyamama" düşüncesinden dolayı yeniden evlenmeyi benimsemedikleri görülmektedir.

Ikinci bir evlilik yaparsam asıl o zaman yalnızlașırım, yani çocuklarım ve çevrem benden uzaklaşır, bu böyledir ama şimdi yalnızım çocuklarım kıymetimi bilir (Saffet, erkek, 68, orta gelir, okuryazar değil).

Yani evlenmek de istiyorum ama nasıl olacak? Íkinci bir evliliğe güvenim yok. Kadın resmi nikâh ister ama mal varlı̆̆ına ortakoluyor (...) Ben bu nedenlerden dolayı evlenemiyorum ama evlensem iyi olurdu yani (Kamil, erkek, 65, alt gelir, okuryazar değil).

Yeniden evliliğe yaklaşım konusunda yaşlı kișilerin gerek bireysel gerekse toplumsal konum açısında homojen olmadıkları; toplumsal cinsiyet kodlarının bireylerin bu olguya yaklaşımını belirlediği ve daha çok kadınları kısıtladığı görülmektedir. Öte yandan ekonomik koșulların hem kadınlar için hem de erkekler için farklı açılardan belirleyici olduğu sonucuna ulaşılmıştır.

\subsection{Ideal yasam aranjmant: Bir ara form olarak çocuklarnna yakın ama tek bașina yaşamak}

Yașlılıkta en büyük değișim iș ve aile ilgili rollerdir. Emeklilik ve eşlerin ölümü, yakın aile üyelerine ve arkadaşlara ulașma olanaksızlığının getirdiği sınırlı sosyal ilișkiler, izolasyon duygusunun ortaya çlkmasına neden olabilir (Hansen-Gandy \& Pastle, 1993; Kalınkara, 2000:78). Dolaylsıyla yaşlı bireyler için çocuklarına yakın olmak ve aile ilişkilerini korumak bu izolasyona bir direnç olarak kabul edilebilir. Bir çok çalıșmada yașlı bireyin ailesine yakın yerde ikamet etme isteğine sahip olduğu saptanmıștır (Görgün-Baran, 2005; Kalaycıŏlu vd., 2003). "Yaşlıların çocuklarıyla aynı çevrede yaşamayı tercih etmesi pek çok araștırmada geleneksel aile bağlarının korunduğuna ilișkin bir gösterge olarak okunmaktadır (Aközer vd., 2011: 107). Bu çalışmada da yaşlı bireyler bir yandan kendi evinde kendi ritmine ve isteğine göre yașayabilme özgürlüğüne sahip olmak isterken, diğer yandan da çocuklarına yakın yerde oturmak istediklerini belirtmişlerdir. Diğer bir deyișle, kendilerine en uygun yașam aranjmanının tek başına yaşamak olduğunu belirtseler de aile fertlerine yakın yaşamanın kendileri için en iyi seçenek olduğunu düşünmektedirler.

Bence en iyisi çocuklarına yakın ama yalnız yașamak. Bu şekilde hem sevilirsin hem de yalnız olduğun için daha değerli olursun (Elif, kadın,73, orta gelir, ilkokul mezunu).

Cocuklarım bana yakın, aynı mahalledeyiz. Bu büyük bir avantaj, hemen bir telefonla geliyorlarya da ben hemen gidebiliyorum (...) Cocuklarımla sık sık görüsürüm, onların saygı ve sevgisinden dolayı kendimiçokiyi hissediyorum (Zahir, erkek, 76, üst gelir, üniversite mezunu).

Yalnız yașamayı tercih ediyorum bir yandan kendi evimde yaşamak diğer yandan çocuklarda bana yakın olması ve ihtiyaç duyduğum anda gelmeleri beni daha mutlu ediyor (Halim, erkek, 74, üst gelir, ilkokul mezunu).

Cocuklarımın her an bana yakın olmaları güzel. Bu güven duygusu içinde tek bașına kalmak en güzeli. Aile desteği önemlidir. Aile yoksa yaşlıları koruyan baska bir sey yok (Ömür, kadın, 70, orta gelir, ilkokul terk).

Cocuklarına yakın oturan yașlı bireyler, biryandan tek başına yaşayarak bağımsız ve kendi ritmine göre yaşamanın, öte yandan ihtiyaç duyduklarında çocuklarıyla bağ kurma imkânı bulmalarının hayatlarını kolaylaștırdığını ifade etmişlerdir. Böylelikle, bu ara form aranjmanında yaşlı bireyler, bir yandan bağımsız, kendi kurallarını kendisinin koyduğu bir hanede yașama firsatı bulurken, diğer yandan da güven ve aidiyet duygusuna sahip olabilme, gündelik işlerde yardım alabilme, çocuklarla, torunlarla daha sık görüşebilme imkânına sahip olabilmektedir. Ancak görüşmeler sonucunda tek bașına yașama durumunun yalnızlık hissi ile özdeșleștirilemeyeceği de anlaşlmaktadır. Ailesiyle beraber ya da ailesine yakın yaşayan yașlı bireyler kendilerini yalnız hissedebileceği (Tufan 2007:189) gibi tek başına yaşayan bireyler de, aksine yalnızlık duygusunu hissetmeyebilirler (Kalaycıoğlu vd., 2003). Bu bağlamda çalışmada ailesine (çocuklarına) yakın yaşayan 16 kișiden 10'u kendisini yalnız hissettiğini ifade ederken 6'sı yalnız hissetmediğini ifade etmiştir. Bu bağlamda yalnızlık hissinin çocuklarına yakın oturmak ya da oturmamakla ilișkisi konusunda bir genelleme yapılamamaktadır. Diğer bir deyișle çocuklara mekânsal yakınlık yalnızlık duygusunu gidermede belirleyici olmamakla beraber daha çok yaşlı bireylerin eksik kaldıkları konularda çocuklarından yardım alabilecekleri, güven ve aidiyet duygusuna sahip olabilecekleri önemli bir faktör olduğu görülmektedir. Yalnızlık duygusu, yaşlı bireyin sosyalleşme ortamına ve çocuklarıyla olan duygusal bağlarına bağlıdır.

Mübeccel Kıray, toplumsal değişmenin "buhran"a ve “çözülme”ye uğramaması için gereken, ne eski ne de yeni yapıya ait olan "müesseseler, ilintiler, değerler ve fonksiyonları," "tampon mekanizmalar" terimi ile ifade eder. Bu tampon mekanizmalar sayesinde, "sosyal yapının çeşitli yönleri birbirine bağlandığını," "fonksiyonel bütünün parçası olmayan tarafların kaybolduğunu" ve bu şekilde "toplumun orta hızda bir değişme oluşumunda da göreli bir denge halinde kalmasının mümkün olduğunu" savunur (Kıray, 2006:96-97). Bu anlamda, modernleşme sürecinde tam bireyselleşmemiş, özellikle yaşlılığa yönelik kurumsal ve toplumsal destek sistemlerinin yeterince gelişmemiş, geleneksel bağlarından tam kopamamıș bir toplumsal formda yașlı bireylerin bir "tampon mekanizma" olarak çocuklarından ayrı ama aynı zamanda çocuklarıyla aynı muhitte yașama biçimi, tek başına yaşayan yaşlı bireylerin hayatını kolaylaştıran bir ara form olarak görülebilir.

Bugün "aile ve toplum, yaşlı bireylerin korunması, bakımı, desteklenmesi ve sağaltımında kilit rol oynamaya" devam etmekte, yașlının bakımında en önemli rol eșe düşmekte, eşin güçsüzleşmesi ve vefatı durumunda ise bakım çocuklara düșmektedir (Halpern, 1987, akt. Aközer vd., 2011:107). Ancak, "koruyucu, denetleyici, destekleyici, dayanıșmacı ve yönlendirici yakın sosyal çevre ve akrabalık gruplarının önemi, modernleşme sürecinde azalmaya yüz tutmuş" (Kalaycı \& Özkul, 2017:95) olsa da yaşl bireylerin bir yandan mümkün olduğunca, kendi ayakları üzerinde durma isteği, kendi ihtiyaçlarına, problemlerine ve gündelik ișlerine çözüm bulmaları öte yandan çocuklarına yakın kalarak onların yardım ve desteklerine ihtiyaç duydukları görülmektedir. 


\section{SONUÇ VE ÖNERILLER}

Bu çalışmada elde edilen veriler ve bulgular doğrultusunda; eşini kaybetmiş veya boşanmış yaşlı bireylerin evde tek başına yaşama kararı almalarının temel nedeninin geniş aile ile beraber yaşamanın zorluklarından kaçınmak isteği olduğu saptanmıştır. Daha önceki dönemlerde aile içerisinde söz sahibi olan ve buna paralel olarak saygı ve otoriteyi elinde bulunduran yaşlı bireyler, değișen ve dönüșen aile yapısı ile beraber artık evlenmiş çocuklarından ayrı yaşamalarının kendileri için daha iyi olacağını düşünmektedirler. Böyle düșünmelerinin sebebi geniş aile içinde yaşarken karşılaştıkları zorluklardır. Özellikle, gündelik hayatlarında hanenin diğer bireyleriyle yaşadıkları ritim farklılıkları; kendi düzenlerini kuramamaları ve mekân düzenlemelerinde söz sahibi olamamaları nedeniyle hissettikleri bağımlılık duygusu; ayrıca evin dar olması, gelin veya damat tarafından istenilmeme ve kendini "yük" olarak görme duygusundan kaçınmaya çalışmaları geniş aileden kopmak istemelerine neden olmaktadır. $\mathrm{Bu}$ anlamda bu çalışmada elde edilen bulgular, modernleşmeyle beraber yaşlı bireylerin bir "otorite ve güç kaybı" yaşadığını, rollerinde büyük kayıpların meydana geldiğini belirten Modernleşme Teorisini ve bir "rolsüzlük rolü" edindiklerini vurgulayan Rol teorisini destekler niteliktedir. Bireyin bir yaşam dengesi kurabilmesi için bu dönemde kayıp rolleri yerine yeni roller edinmelidir. Bu doğrultuda tek bașına yaşama tercihi, yaşlı bireylerin en azından kendi evindeki otoritesini korumak, kendi hayatı üzerinde söz sahibi olabilmek ve bu kayıpları mümkün olduğunca azaltmak için bir yaşam stratejisi olarak düşünülmektedir.

Tek başına yaşama aranjmanını tercih eden katılımcıların, huzurevinde yașama veya evlenme gibi aile $\mathrm{dl}_{\mathrm{l}}$ şında bașka seçeneklere de olumsuz yaklaștıkları görülmektedir. Yaşlıların huzurevine bırakılmasını toplumsal olarak bir "ayıbın" göstergesi, huzurevini de "düşkünler evi" olarak yorumlamakta ve bu nedenle huzurevini ancak kimsesiz kaldıklarında ve tek bașına yașayamadıklarında bir "son çare" olarak görmektedirler. "Yeniden evlenme" ve eşle yaşama konusuna ise nedenselleștirmeleri farklı olsa da kadınlar ve erkekler yine genelde olumsuz yaklaşmaktadırlar. Yeniden evlenmeye kadınlar, toplumsal cinsiyet kalıpları doğrultusunda toplum tarafından hoș karşılanmadığı için ve kendi kendilerine yetebildikleri düşüncesi ile karşı dururken; erkekler miras malının bölünmemesi ve bu konuda çocuklarıyla bir sorun yaşamamak için ve "dolandırılma" korkusu yaşadıkları için pek sıcak bakmamaktadırlar. Sosyal yapılandırmacı teori yaș'ın ve yașlılığın "toplumsal anlamları ve öz-algılanışının" toplumsal bir söylem üzerinden șekillendiğini ve bireyin yașlanma deneyimini etkilediğini ifade eder. Bu çalışmada da olumsuz toplumsal söylemler yaşlıların huzurevi ve yeniden evlenmeye dair algılarını etkilerken hatta bu algı kendileri tarafından da yeniden üretilirken, yaşlı bireyin yaşlanma deneyimi kısıtlanmakta, çözülen geleneksel aile dışında kalan yaşlı bireye, başka bir yaşama kompozisyonu alternatifi de olmadığından tek bașına kalmak dışında pek bir seçeneği kalmadığı görülmektedir. Çalışmanın bu çıktıları, toplumsal değişim dönüşüm ile beraber yaşlı bireyler için tek başına yaşama aranjmanı seçiminin artacağını göstermektedir.
Çalışmada, tek başına yaşama aranjmanı, yaşlı bireyler için en uygun hane kompozisyonu olsa da çocuklara yakın olma durumunun bu aranjman kapsamında çok büyük önem arz ettiği görülmektedir. Bu ara formda yașlı bireyler böylece bir yandan, kendi ayakları üzerinde durdukları, kendi kurallarını kendilerinin koyduğu bir hanede yaşama firsatı bulurken; diğer yandan da çocuklarına mekânsal yakınlığı ile kendilerini güvende hissetmektedirler.

Türkiye'de yaşlıların kendi evlerinde yalnız yaşayarak bağımsız bir hayat sürmeyi istediklerini ancak çocuklarına yakın oturarak da onlara manevi destek olmayı tercih ettiklerini öne süren (Ünalan, 2000, akt. İçli, 2008:37) ve yaşlıların gerek çocuklarını rahatsız etmemek için, gerekse kendileri rahat edemeyeceklerinden kendi evlerinde oturmayı ve çocuklarının sık sık kendilerini ziyaret etmesini tercih ettiklerini (Görgün-Baran, 2003:135, akt. İçli, 2008:36-37) belirten başka çalıșmalar da yapılmıștır.

Bu çalışmada da bir yandan sanayileșen, öte yandan geleneksel ilișkileri baskın olan Gaziantep'te modernlik ve geleneksellik arasındaki değişim sürecini yaşayan yaşlı bireylerin ne geniş ailede kalmak ne de huzurevini ve yeniden evlenmeği bir alternatif olarak görmemeleri dolayısıyla, çocuklarına mekansal olarak yakın ama tek başına yaşadıkları bu ara formun yașlı bireyler için en uygun yaşam aranjmanı olduğu sonucuna ulaşlmıştır. Ancak her kent ve toplumun özgül özellikleri olduğu gerçeğinden yola çıkarak bu yönde bir tespitin ne kadar genellenebileceği farklı bölgelerde yapılacak benzer çalışmalarla ortaya konulabilir.

Yaşlanma olgusu bireysel değil, toplumsal bir olgudur. Toplumsal yaşlanma gerçekliği de dikkate alındığında, yaşlı bireylere yönelik sosyal, kültürel, ekonomik ve sağlık destek programları uygulanırken, ya da bu ara formun uygulanabilmesi için konut mimarisi planlanırken yaşlı bireylerin ihtiyaçlarının yaşam aranjmanlarına göre belirlenmesi önemlidir. Bu anlamda gerek Aile, Çalışma ve Sosyal Hizmetler Bakanlığı'nın gerek de yerel yönetimlerin sayıları gittikçe artan tek başına yaşama aranjmanına sahip yaşlı bireylerin yaşam koşullarını dikkate alarak iyileştirecek, kendi kendilerine yetebilmelerine destek olacak, toplumsal katılımlarını ve topluma katkıda bulunmalarını sağlayacak politikalar geliştirmeleri önem arz etmektedir.

\section{KAYNAKÇA}

Aközer, M., Nuhrat, C., \& Say, Ș. (2011). Türkiye'de yașlılı dönemine ilişkin beklentiler araştırması. Aile ve Toplum Dergisi, 12(7), 103-128.

Aksoydan, E. (2008). Yaşlılık ve Beslenme. Sağlık Bakanlığı, Yayın No: 726. Ankara: Klasmat Matbaacllık.

Arun, Ö., \& Arun, B. (2011). Türkiye'de yaşlı kadının en büyük sorunu: Dulluk. Gaziantep Üniversitesi Sosyal Bilimler Dergisi, 10(4), 1515-1525.

Aslan, D., Şengelen, M., \& Bilir, N. (2008). Yaşlılık Döneminde Beslenme Sorunları ve Yaklașımlar. Geriatri Derneği. Ankara: Öncü Basımevi.

Aytaç, A. M. (2007). Ailenin Serencamı, Türkiye'de Modern Aile Fikrinin Oluşması. Ankara: Dipnot Yayınları,

Bengtson, V. L., Burgess, E. O., \& Parrott, T. M. (1997). Theory, explanation, and a third generation of 
theoretical development in social gerontology. Journal of Gerontology: Social Sciences, The Gerontological Society of America, 52B(2), 72-88.

Bingöl, C., Varma, G. S., Enli, Y. Ö., \& Karaca, Ö. (2017). Yaşlılık ve erişkinlik dönemi depresyonunda fenomenolojik karşlaștırma. Anatolian Journal of Psychiatry, 18(5), 446-452.

Geniş, Ş., \& Adaş, E. B. (2011). Gaziantep kent nüfusunun demografik ve sosyoekonomik yapısı: Saha araştırmasından notlar. Gaziantep Üniversitesi Sosyal Bilimler Dergisi, 10(1), 293-321.

Giddens, A. (2013). Sosyoloji. Güzel, C. (Ed.). İstanbul: Kırmızı Yayınları.

Görgün-Baran, A. (2004). Yașlılık sosyolojisi. Yașlılık: Disiplinler Arası Yaklaşım, Sorunlar, Cözümler. Kalınkara, V. (Ed.). Ankara: Odak. (s. 35-57).

Görgün-Baran, A., Kalınkara, V., Aral, N., Baran, G., Akın, G., Özkan, Y. (2005). Yaşlı ve Aile Illişskileri: Ankara Örneği. Başbakanlık Aile ve Sosyal Araştırmalar Genel Müdürlüğü Yayınları No:127. Ankara.

Hablemitoğlu, S.., \& Özmete, E. (2010). Yaşlı Refahı: Yaşlılar Íçin Sosyal Hizmet. Ankara: Kilit Yayınları.

Hooyman, N., Kiyak, H. A., \& Kawamoto, K. (2015). Aging Matters: An Introduction to Social Gerontology. Boston: Pearson.

İçli, G. (2004). Huzurevinde kalan yaşlılar üzerine bir araştırma. Sosyoloji Araştırmaları Dergisi, 7(1), 5-24.

İçli, G. (2008). Yaşlılar ve yetişkin çocuklar. Yaşı Sorunları Araştırma Dergisi, 8(1), 29-38.

Kalaycı, I., \& Özkul, M. (2017). Geleneksel kalabilsem modern olabilsem: Modernleşme sürecinde yaşlılık deneyimleri. Süleyman Demirel Üniversitesi Vizyoner Dergisi, 8(18), 90-110.

Kalaycioğlu, S., Tol, U., Küçükural, U., \& Kurtuluș, Ö. C., (2003). Yașlılar ve Yașlı Yakınları Açısından Yaşam Biçimi Tercihleri. Ankara: TÜBİTAK Matbaasl.

Kalenderoğlu, A., Yumru, M., Selek, S., Cansel, N., Virit, O. \& Savaş, H.A. (2007). Anadolu Psikiyatri Dergisi, 8, 179-185.
Kalınkara, V. (2000). Yaşlılıkta sosyal katılım ve kent hizmetleri. Antropoloji ve Yaşlılı. Erkan, G. \& Işıkhan, V. (Ed.). Ankara: Hacettepe Üniversitesi Sosyal Hizmetler Yüksekokulu Yayın No: 006: 7786.

Karaca, F. (2010). Huzurevinde kalan yaşlıların hayata bakış açları ve gelecekle ilgili beklentileri. Aile ve Toplum, 11(6), 50-72.

Kaygusuz, C. (2008). Yașlılık kuramları. Psikolojik, Sosyal ve Bedensel Açıdan Yaşlılık. Kalkan, M.(Ed.). Ankara: Pegem Akedemi. (s.215-298)

Kıray, M. (2006). Toplumsal Yapı Toplumsal Değișme. İstanbul: Bağlam Yayıncılık.

Murakami, İ. (2014). Tek bașına yașayan yașlı kadınların kișisel iletișim ağı: Ankara örneği. 6th International Social \& Applied Gerontology Symposium. Arun, Ö. (Ed.). Antalya Gerontoloji Bölümü Yayınları Sempozyum Kitapları, Antalya. (s.145-160).

Quadagno, J. (2002). Aging and the Life Course. Boston: McGraw Hill.

Şentürk, M., \& Altan, R. B. (2015). Giriș: İstanbul'da yaşlıların mevcut durum araştırması. Ístanbul'da Yaşlanmak. Şentürk, M., \& Ceylan, H. (Ed.). İstanbul: Açlım Kitap. (s. 13-34).

Tufan, İ., Zengin, M., \& Köse, M.(2017). Sosyal gerontoloji. Gerontoloji - Kapsam, Disiplinler-arası İs Birliği, Ekonomi ve Politika, Cilt 1. Tufan, İ. \& Durak, M. (Ed.). Ankara: Nobel Akademik Yayıncılık. (s. 73-87).

Tufan, İ. (2007). Birinci Türkiye Yaşhllık Raporu. Antalya: Geroyay.

Tufan, İ. (2002). Antik Cağdan Günümüze Yaşlılık-Sosyolojik Yaşlanma. İstanbul: Aykırı Yayıncılık.

Tufan, İ. (2003). Modernleșen Türkiye'de Yaşlillk ve Yaşlanma: Yaşlanmanın Sosyolojisi. İstanbul: Anahtar Kitaplar Yayınevi.

TUİ (2017). Türkiye istatistik kurumu Haber Bülteni, Sayı 27595, 15 Mart 2018. http://www.tuik. gov.tr (01.06.2019). 